\title{
Uses of wild vertebrates in traditional medicine by farmers in the region surrounding the Serra do Conduru State Park (Bahia, Brazil)
}

\author{
Joanison Vicente dos Santos Teixeira ${ }^{1,2,3}{ }^{\circledR}$, Jade Silva dos Santos ${ }^{3,4}$, Deyna Hulda Arêas Guanaes ${ }^{4}$ \\ Wesley Duarte da Rocha ${ }^{4}$ \& Alexandre Schiavetti ${ }^{3,5}$ \\ ${ }^{1}$ Universidade Estadual de Santa Cruz, Programa de Pós-Graduação em Zoologia, Rodovia Jorge Amado, \\ Km 16, Bairro Salobrinho, CEP 45662-900, Ilhéus, BA, Brasil \\ ${ }^{2}$ Universidade Estadual de Santa Cruz, Programa de Pós-Graduação em Ecologia e Conservação da \\ Biodiversidade, Rodovia Jorge Amado, Km 16, Bairro Salobrinho, CEP 45662-900, Ilhéus, Bahia, Brasil \\ ${ }^{3}$ Universidade Estadual de Santa Cruz, Departamento de Ciências Agrárias e Ambientais, Laboratório de \\ Etnoconservação e Áreas Protegidas, Rodovia Jorge Amado, Km 16, Bairro Salobrinho, CEP 45662-900, \\ Ilhéus, Bahia, Brasil \\ ${ }^{4}$ Universidade Estadual de Santa Cruz, Programa de Pós-Graduação em Desenvolvimento Regional e Meio \\ Ambiente, Rodovia Jorge Amado, Km 16, Bairro Salobrinho, CEP 45662-900, Ilhéus, Bahia, Brasil \\ ${ }^{5}$ Centro Nacional Patagónico, Centro Para el Estudio de Sistemas Marinos, Puerto Madryn, Chubut, Argentina \\ *Corresponding author: Joanison Vicente dos Santos Teixeira, e-mail: joanison1990@gmail.com
}

TEIXEIRA, J. V. S., SANTOS, J. S., GUANAES, D. H. A., ROCHA, W. D., SCHIAVETTI, A. Uses of wild vertebrates in traditional medicine by farmers in the region surrounding the Serra do Conduru State Park (Bahia, Brazil). Biota Neotropica. 20(1): e20190793. http://dx.doi.org/10.1590/1676-0611-BN-2019-0793

\begin{abstract}
Wild and domestic animals and their by-products are important ingredients in the preparation of medicines traditionally used in folk medicine, present in various human cultures since antiquity. However, the decline in the number of species in neotropical regions as a result of hunting for various purposes, including food, medicine and magico-religious use, has placed some species - especially endemic species - at risk of extinction. In this context, the present study aimed to identify the wild vertebrate species used in folk medicine in five communities in the region surrounding the Serra do Conduru State Park (PESC), Bahia, Brazil. Forty-five hunter-farmers were interviewed, citing 23 species, from which 17 raw materials are extracted for prevention and/or treatment of 19 illnesses. Mammals were the most cited taxon followed by birds and reptiles. Among the species mentioned, Cuniculus paca is the most used for zootherapy purposes, followed by Salvator merianae and Sphiggurus insidiosus. There was dissimilarity between the communities in relation to the diversity of species used for zootherapy. Ten categories of body systems were classified for which the therapeutic resources are recommended. Disorders related to the middle and inner ear were the most cited. Some of the species mentioned are endangered, such as Bradypus torquatus and Lachesis muta. This research demonstrated that zootherapy is a traditional practice embedded in these communities. Further studies are needed to broaden knowledge of other species that may have important cultural value for these families, as well as to evaluate the potential implications of the uncontrolled use of these species in traditional medicine in an ecological context, since the practice of zootherapy can excerpt pressure on critical animal populations and threaten biodiversity.
\end{abstract}

Keywords: Ethnozoology, zootherapy, conservation, Serra do Conduru.

\section{Usos de vertebrados silvestres na medicina tradicional por caçadores-agricultores da região do entorno do Parque Estadual Serra do Conduru (Bahia, Brasil)}

Resumo: Animais silvestres, domésticos e seus subprodutos são ingredientes importantes na preparação de medicamentos tradicionalmente utilizados na medicina popular, presentes em várias culturas humanas desde a antiguidade. No entanto, a diminuição do número de espécies nas regiões neotropicais, por meio da caça para diversas finalidades, como uso alimentar, medicinal e mágico-religioso tem colocado espécies em risco de extinção, especialmente as endêmicas. Nesse contexto, o presente estudo objetivou identificar as espécies de vertebrados silvestres utilizadas na medicina popular em cinco comunidades na região do entorno do Parque Estadual Serra 
do Conduru (PESC), Bahia, Brasil. Foram entrevistados 45 caçadores-agricultores que citaram 23 espécies os quais são extraídas 17 matérias-primas para prevenção e/ou tratamento de 19 enfermidades. Os mamíferos foi o táxon com maior número de citações, seguido pelas aves e répteis. Dentre as espécies citadas a Cuniculus paca é a mais utilizada para fins zooterápicos, seguido por Salvator merianae e Sphiggurus insidiosus. As comunidades apresentaram uma dissimilaridade em relação a diversidade de espécies de uso zooterápicos. Foram classificadas 10 categorias dos sistemas corporais para os quais os recursos terapêuticos são recomendados. Transtornos relacionados ao ouvido médio e interno foram os mais citados. Algumas espécies citadas encontram-se ameaçadas de extinção, como a Bradypus torquatus e Lachesis muta. A pesquisa mostrou que a zooterapia é uma prática tradicional inserida nas comunidades. Estudos adicionais são necessários para ampliar o conhecimento sobre demais espécies que possivelmente desempenham importante valor cultural às famílias, bem como avaliar em um contexto ecológico às implicações que pode acarretar com o uso descontrolado dessas espécies na medicina tradicional, uma vez que a prática da zooterapia pode causar pressão sobre populações animais críticas e ameaçar a biodiversidade.

Palavras-chave: Etnozoologia, zooterapia, conservação, Serra do Conduru.

\section{Introduction}

Humans have always used nature as a source of survival resources, including disease and illness treatments, with traditional medical practices including the use of plants, animals and minerals to produce remedies (Alves \& Rosa 2012, Alves \& Souto 2010, Souto et al. 2000). Traditional forms of medicine have been strongly incorporated into contemporary societies, including phytotherapy and zootherapy, which are among the various therapeutic alternatives used throughout the world (Alves \& Rosa 2005). In modern societies, zootherapy is an important alternative alongside the many other known therapies that are practiced (Adeola 1992). Wild and domestic animals and their by-products are important ingredients in the preparation of traditionally-used medicines (Anageletti et al. 1992) and have been present in various human cultures since antiquity (Gómez-Ulla 1983, Lev 2003).

Worldwide, studies on zootherapy have increased in the last years, demonstrating that this practice is common in various parts of the world (Alves \& Rosa 2007a,b, Alves 2007, Kakati et al. 2006, Lev 2003, 2006, Mahawar \& Jaroli 2006, Mahawar \& Jaroli 2007, Negi \& Palyal 2007, Pieroni et al. 2002). In Latin America, many cultures still resort to animal-derived remedies as part of their traditional medicine practices, most of them deeply rooted in a long-standing tradition of wild fauna use, including many endangered species, to treat all kinds of diseases (Martínez 2013). In México the use of 18 species was recorded in Mapimi, Durango (Jacobo-Salcedo et al. 2010), 24 species in San Luis Potosí (Alonso-Castro et al. 2011), and 74 species in the state of Chiapas (Enriquez Vazquez et al. 2006). More than 20 species used by the Izoceño-Gurani from the South East Bolivia (Bourdy et al. 2004) and 14 species traded in the Bolivian rain forest (Apaza et al. 2003) were also reported.

In Brazil, publications containing quantitative data on zootherapy have recorded that about 290 species of animals are used in Brazilian traditional medicine (Almeida 2007, Alves 2008, Alves et al. 2007, Alves \& Rosa 2006, 2007a,b). Specifically in Northeast Brazil, zootherapy is a very common practice (Alves 2009, Alves \& Rosa 2005, Costa-Neto 2002), evidenced, for example, by the use of about 95 animal species in folk medicine in the state of Bahia (Costa-Neto 2011), 36 species in the semiarid region of Pernambuco (Alves et al. 2009) and 51 species in the Caatinga Biome in the state of Paraiba (Alves et al. 2011). However, the decrease in the number of species, especially in neotropical regions, through hunting, structural changes to ecosystems and varied uses has led to the extinction of species before science has even had a chance to study them (Costa-Neto 2011).

In recent years, studies have shown that the link between traditional medicine and the loss of certain species has become apparent (Alves et al. 2007, Call 2006) showing that zootherapeutic use has an additional impact on wildlife populations (Alves et al. 2013, Rosa et al. 2011). This follows the tendency already observed in other countries, especially in Asia, where some species have been heavily targeted for traditional medicine (Kikuchi 2012, Zhang et al. 2008). Thus, studies of zootherapy and its significance for human communities should be conducted in order to determine the best way to exploit natural resources, leading to the long-term sustainable use of animals used culturally for this purpose (Alves \& Rosa 2006). In addition to providing information about the species utilized for traditional purposes (medicinal, religious, food, etc.), which can contribute to the development of actions that allow the maintenance of faunistic resources (Almeida \& Albuquerque 2002, Alves 2009, Alves \& Rosa 2010).

In this context, the present study aimed to identify and characterize the wild vertebrate species used by hunter-farmers in traditional medicine in the region surrounding the Serra do Conduru State Park (PESC), located in the Atlantic Forest (Mata Atlantica) of the state of Bahia, Brazil. The following questions were addressed in the field study: which species are used for medicinal purposes? What body parts are used for the preparation of these remedies? What diseases are treated by these remedies?

\section{Materials and Methods}

\section{Study area}

The Serra do Conduru State Park (14 26' 53” S; $39^{\circ} 05^{\prime}$ '36” O) (Figure 1) is a full protection Conservation Unit (CU) with a total area of 9,275 hectares, created by State Decree N ${ }^{\circ} .6,227$ of February 21, 1997, in exchange for the perpetuation of a highway (BA 001) (Bahia 2005). It is located within the Costa de Itacaré/Serra Grande Environmental Protection Area (APA). Both have the conservation of the remnants of the Atlantic Forest and the biodiversity of southern Bahia as one of their objectives (Bahia 2005, MMA 2004). 


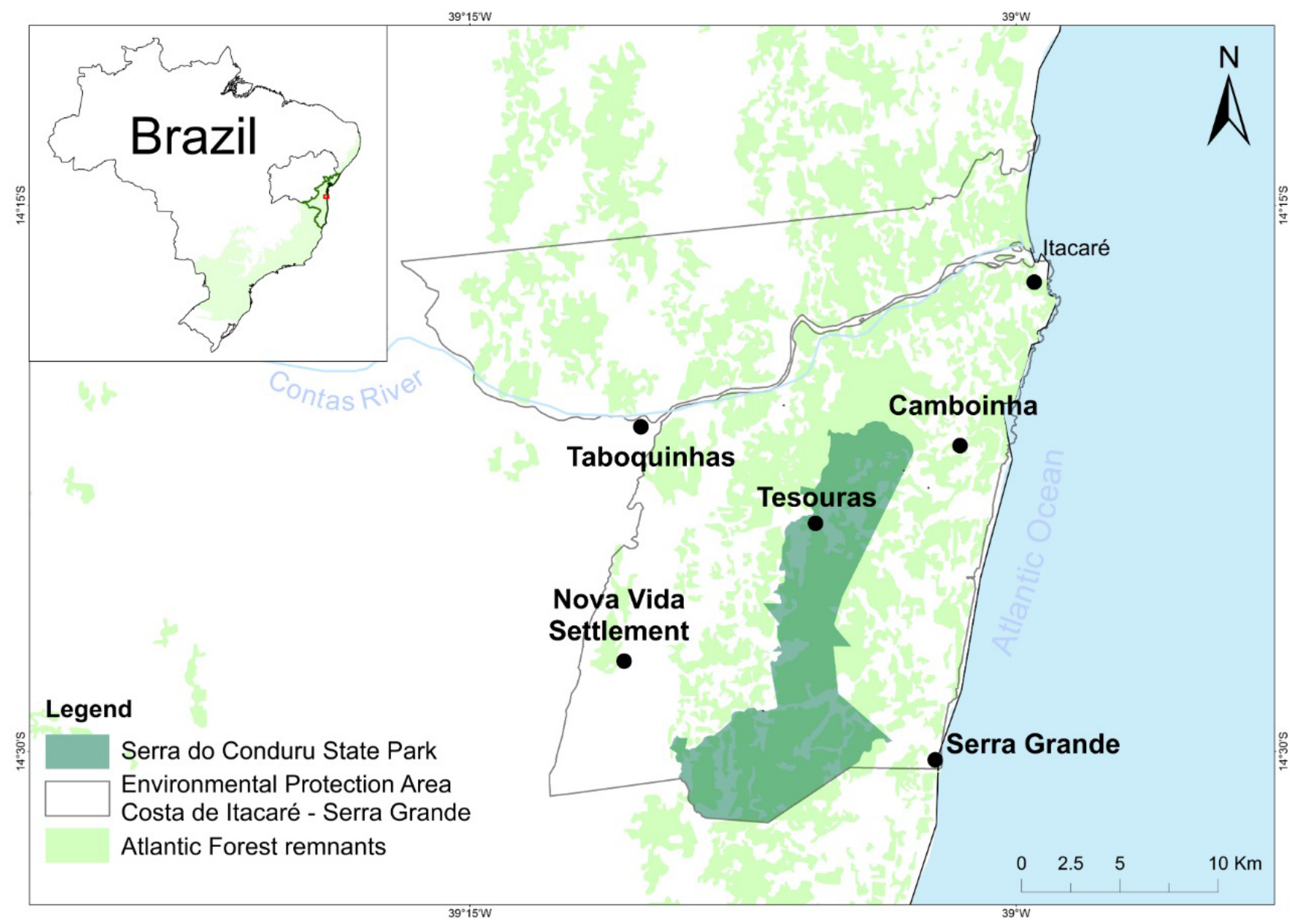

Figure 1. Map of the study area identifying the Serra do Conduru State Park; Costa de Itacaré/Serra Grande Environmental Protection Area; the municipality of Itacaré and the communities in which the field study was carried out with hunters: Camboinha Settlement (AC), Community of Tesouras (CT), Nova Vida Settlement (NV), District of Serra Grande (SG) and District of Taboquinhas (DT).

In the inventory of the PESC management plan, 39 species of mammals were recorded, eight endemic to the Atlantic Forest and four endemic to the Atlantic Forest of southern Bahia (Bahia 2005). Previous studies conducted in the region during the "South Bahia corridor" (IESB/ PROBIO/MMA) project in 1999/2002 identified at least 45 amphibian species, including endemic and endangered species; 175 species of birds, 27 endemic and 6 endangered; 9 species of small mammals and 30 species of medium and large mammals, some of which are endangered (Silvano \& Pimenta 2003, Cordeiro 2003, Moura 2003).

For this reason, the Atlantic Forest of southern Bahia is indicated as a priority area for conservation. It is here that the most important remnants of Atlantic Forest in the Northeast of Brazil are found, rich in biodiversity and endemic species, considered to be of high biological importance (Alger \& Caldas 1994, Leol-Galindo \& Câmara 2003, Martini et al. 2007, MMA, 2000).

The study was undertaken in five communities in the region: District of Serra Grande (SG), District of Taboquinhas (DT), Nova Vida Settlement (NV), Camboinha Settlement (AC) (located within the Costa de Itacaré/Serra Grande APA and in the region surrounding the PESC) and the Community of Tesouras (CT) (within the limits of the PESC) (Figure 1). Hunting is prohibited in all of the communities (Instituto Ynamata, 2008).
Serra Grande ( $\left.14^{\circ} 27^{\prime} 53^{\prime \prime} \mathrm{S} ; 39^{\circ} 02^{\prime} 24^{\prime \prime} \mathrm{W}\right)$ is a district of the municipality of Uruçuca in the south of Bahia. It was founded in 1941 and is located almost $40 \mathrm{~km}$ from the municipality's center. It has an estimated population of 3,585 inhabitants, $74 \%$ residing in the urban area and 26\% in rural areas (Instituto Ynamata, 2008).

The district of Taboquinhas (14\% 21' $24^{\prime \prime} \mathrm{S}$; $\left.39^{\circ} 10^{\prime} 30^{\prime} \mathrm{W}\right)$ is located $28 \mathrm{~km}$ from the municipality of Itacaré. Before tourism the economy was based on the cultivation of cacao, but with the fall of the crop and the advance of tourism the district began to value its natural wealth more. The Camboinha Settlement ( $14^{\circ} 21^{\prime} 35^{\prime \prime}$ S; 39०02' $12^{\prime}$ " W), located between the district of Serra Grande and Itacaré, is made up of small farmers who dedicate themselves to agriculture and local handicrafts (Instituto Ynamata, 2008, Sema 2005).

The Nova Vida Settlement (14²9' 45" S; 39 $12^{\circ}$ ' 14" W) consists of small farmers who were expropriated during the implementation of the PESC and who came from the communities of Serra Azul and Tesouras, alongside the old residents of the community itself. The community is made up of 44 families whose income is based on family farming (Ribeiro \& Schiavetti 2009, Sema 2005).

Tesouras is a community $\left(14^{\circ} 23^{\prime} 41^{\prime}\right.$ ' $\left.\mathrm{S} ; 39^{\circ} 05^{\prime} 21^{\prime \prime} \mathrm{W}\right)$ composed of 8 families residing within the PESC. Even though human presence is prohibited within the full protection $\mathrm{CU}$, these families still reside 
inside the park due to the slow process of land regularization (Ribeiro $\&$ Schiavetti 2009, Sema 2005). In view of this, the major problems related to the implementation of the PESC at present are the presence of residents inside the park who continue to carry out agricultural and hunting activities, and the constant removal of timber from the area of the Park (Sema 2005).

\section{Data collection}

Data collection took place between September 2016 and July 2017. Only farmers who had been engaged in hunting in the region for at least two years or who have hunted for at least a two-year period of their lives and who use animal by-products for zootherapeutic purposes, participated in the study. As such, 45 informants (44 men and 1 woman) aged 18 to 90 participated in the study. Each informant was interviewed only once.

The respondents were selected by the criterion of native experts, i.e. those who recognize themselves and are recognized by the community as culturally competent (Hays 1976) and by the snowball sampling technique (Bailey 1982). These two techniques made it possible to interview all hunters who use zootherapeutic products in the region. Sampling was non-random intentional, in which the interviewees were pre-defined (Albuquerque \& Paiva 2004). Thus, only hunters who use zootherapeutic products participated in the research.

Information was obtained through open and semi-structured interviews, complemented by informal conversations (Huntington 2000). During the interviews questions about the animal species used for medicinal purposes, their respective uses, preparations and parts utilized. The free-listing technique was used to record the names of the animals used by the respondents, based on the principle that the most culturally important elements appear in many of the lists in order of cultural importance (Albuquerque et al. 2008). In order to overcome the existing limitations of free-listing, non-specific induction prompting and reading back were performed (Albuquerque et al. 2008).

To respect intellectual property rights, we adopted the following protocol in the field: before the survey, we introduced ourselves, explained the nature and objectives of our research and asked the respondents for permission to record the information. Prior to each interview, a Free and Informed Consent Form (TCLE) and an authorization term for the use of images were submitted to the respondents, according to the norms established by Resolution No. 196 of the National Health Council of 10/1996 and approved by the Committee of Ethics in Research with Human Beings (CEP) of the State University of Santa Cruz (Caae 61683516.2.0000.5526).

The vernacular names of the medicinal specimens were recorded as denominated by the respondents and identified according to the specimens, or parts thereof, donated by the respondents; photographs of the animals taken during the interviews and/or photographs shown to the interviewees; and with the help of taxonomists familiar with the fauna of the study area (Alves \& Rosa 2006), and based on zoological and ethnozoological studies carried out in the study area (Argôlo 2004, Castilho et al. 2013, Lobão 2011, Pereira \& Schiavetti 2010, Ribeiro \& Schiavetti 2009, Sema 2005, A. E. Encarnação, dados não publicados).
The classification and nomenclature used followed the specifications of the Brazilian Ornithological Records Committee for birds (CBH 2014) and the Brazilian Society of Herpetology (SBH 2016) for reptiles. For mammals, the 2nd edition of the Annotated Mammalian List of Brazil was consulted (Paglia et al. 2012). The Red Book of Endangered Brazilian Fauna (Machado et al. 2008), the IUCN Red List (International Union for Conservation of Nature) (IUCN 2014) and the official list of endangered species of the state of Bahia (SEMA 2017) were consulted to ascertain the conservation status of the species recorded. All material collected in the field was registered and deposited in the Alexandre Rodrigues Ferreira Mammalian Collection (CMARF) of the State University of Santa Cruz (UESC).

\section{Data analysis}

The results were analyzed qualitatively, according to the unified model of individual competence, according to which all information regarding the research subject is considered (Marques 1991). The diseases treated with zootherapeutic resources cited by the interviewees were distributed into 10 categories, based on the tenth revision of the International Statistical Classification of Diseases and Related Health Problems (CID, 2008) as follows: (1) chronic diseases; (2) sexual dysfunction; (3) skin and subcutaneous tissue diseases; (4) neoplasia (5) problems in the skeletal system; (6) middle ear and inner ear disorders; (7) disorders of the circulatory system; (8) disorders of the teeth and their supporting structures; (9) disorders in the respiratory system; (9) disorders in the urinary system and (10) indefinite diseases.

The influence of the five communities surveyed on the species composition cited by the interviewees was tested using a permutational multivariate analysis of variance (Anderson 2005). We used Jaccard distance and 1000 permutations. PERMANOVA uses the "Adonis" procedure in the vegan package for R (Oksanen 2011). We also used non-metric multidimensional scaling (NMDS) to represent the results of the PERMANOVA analyses. In the NMDS, we also used the Jaccard for the ordination of species composition. All analyses were performed in the software R (Development Core Team R 2017).

\section{Results}

\section{Species of medicinal use}

In the present study, 23 wild vertebrate species from 21 families were identified from which 17 raw materials were extracted to prevent or treat 19 traditionally recognized illnesses (Table 1). Only two families are composed of two species: Canidae (Nasua nasua and Cerdocyon thous) and Dasypodidae (Dasypus novemcinctus and Euphractus sexcinctus), the other families are represented by a single species. All species mentioned are native to the regionand are caught within the hunter's residence limits. Mammals were the taxon with the highest number of species mentioned, followed by reptiles and birds (Table 1). The paca Cuniculus paca, the tegu Salvator merianae, the Bahia hairy dwarf porcupine Sphiggurus insidiosus, the six-banded armadillo Euphractus sexcinctus, the ninebanded armadillo Dasypus novemcinctus, the South American bushmaster Lachesis muta, the coati Nasua nasua and the sloth Bradypus sp. were the species with the highest number of mentions. 
Table 1. Species of wild animals used in traditional medicine in the PESC region.

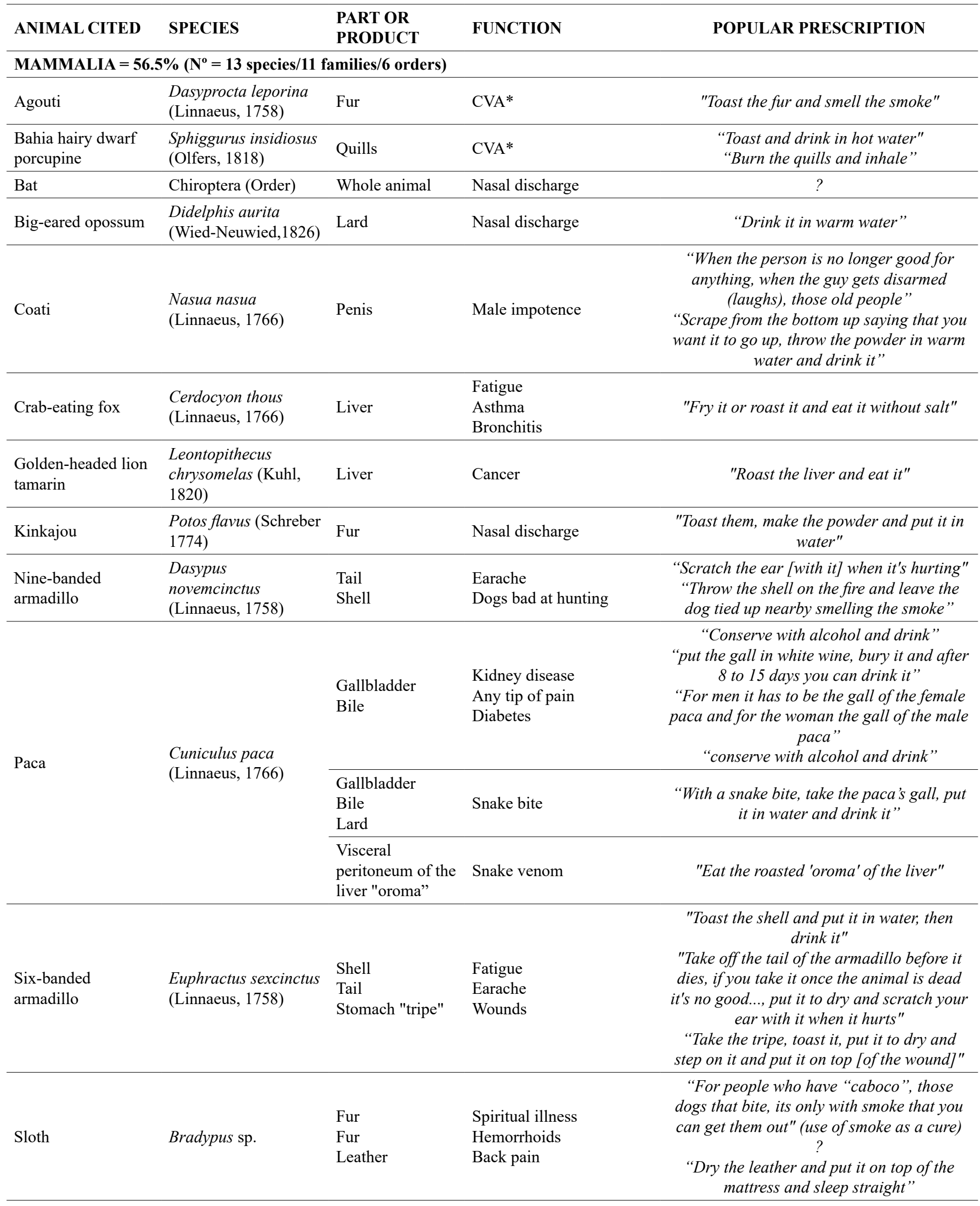


Continuation Table 1.

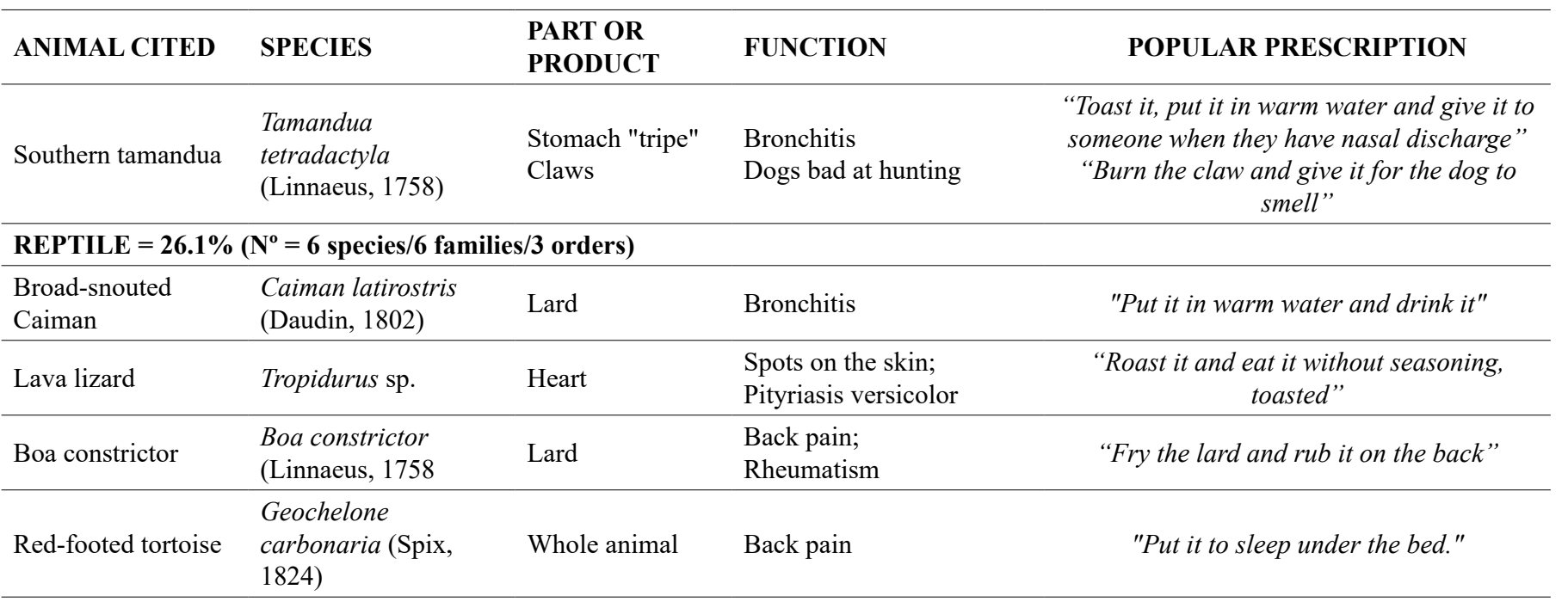

"Fry the lard and throw drops on the site and drink a little as well"

\begin{tabular}{|c|c|c|c|}
\hline \multirow{8}{*}{ Tegu } & \multirow{8}{*}{$\begin{array}{l}\text { Salvator merianae } \\
\text { (Duméril \& Bibron, } \\
\text { 1839) }\end{array}$} & Lard & Snakebite prevention \\
\hline & & Lard & Rheumatism \\
\hline & & Lard & Cough \\
\hline & & Lard & Back pain \\
\hline & & Lard & Pityriasis versicolor \\
\hline & & Lard & Spots on the skin \\
\hline & & Lard & Earache \\
\hline & & Lard & Toothache \\
\hline
\end{tabular}

"Fry the lard and put it on and rub on top"

"Put it in warm water and drink it"

"Fry the lard and put it on and rub on top"

"Rub the fried lard at the site"

"Rub the lard at the site of the pain"

"Rub the conserved lard on the site of the spot"

"Conserve the lard and when you use it you just heat it up and put it in the ear"

"Rub the lard at the foot of the tooth, the tooth will rise, rise rise... in no time it falls"

"Make the dog eat it raw"

"Eat it roasted, if a snake bites you, you don't feel anything"

$\begin{array}{ccc}\text { Liver } & \text { Terminal disease in dogs } & \text { "Eat it roasted, if a snake bites you, you } \\ \text { Liver } & \text { Snakebite prevention } & \text { don't feel anything" }\end{array}$

South American

Lachesis muta

Venom

Cancer

Liver Rheumatism

Liver Back pain

"Toast the lard and conserve it in alcohol, rub it on the site every night"

"Toast the lard and conserve it in alcohol, ask someone to rub it on the spine"

\begin{tabular}{|c|c|c|c|c|}
\hline \multicolumn{5}{|c|}{ BIRDS $=17.4 \%\left(N^{0}=4\right.$ species $/ 4$ families $/ 3$ orders $)$} \\
\hline Black vulture & $\begin{array}{l}\text { Coragyps atratus } \\
\text { (Bechstein, 1793) }\end{array}$ & Feathers & CVA* & $\begin{array}{c}\text { "The person has to smell the burned } \\
\text { feathers" }\end{array}$ \\
\hline Solitary tinamou & $\begin{array}{l}\text { Tinamus solitarius } \\
\text { (Vieillot, 1819) }\end{array}$ & Feathers & CVA* & $\begin{array}{l}\text { "Burn the feathers of the animal and stay } \\
\text { close to the smell" }\end{array}$ \\
\hline
\end{tabular}

Wild vertebrates used in traditional medicine by hunter-farmers in the Serra do Conduru State Park region. Recorded: June/16 to June/17. (?) Did not know how to respond. (*) Cerebrovascular accident. Source: research data. 
The Bile (secreted by the liver and stored in the gallbladder, traditionally recognized as "gall") was the main raw material used from the paca, which hunters regarded as "a holy remedy" and with therapeutic powers for various diseases, usually taken in warm water, white wine or alcohol (Figure 2). Tegu lard was the only by-product extracted from the species and used as a medicinal resource in the region to treat various illnesses such as rheumatism, back pain and toothache.

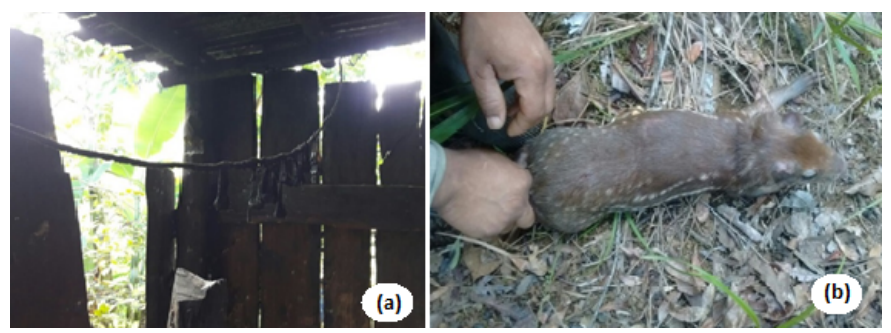

Figure 2. (A) Gallbladder of the paca Cuniculus paca (Linnaeus, 1766) preserved by smoking in a wood stove at the hunter's residence. (B) Cuniculus paca (Linnaeus, 1766) captured by a hunter from the region of the Serra do Conduru State Park. Recorded: June/16 to June/17. Photo: Author.

The thorn of the Bahia porcupine is used as a medicine to treat cerebrovascular accidents, a condition known to hunters as "stroke". The tail of the armadillo species Euphractus sexcinctus and Dasypus novemcinctus is used to treat diseases related to the auditory system where the raw material serves as an instrument to scratch the ear at the time of earaches. In addition to their use for zootherapy, the use of wild species for food was also observed.

There was dissimilarity between the five communities regarding the composition of species used medicinally (PERMANOVA, $\mathrm{p}=0.04$ ). Eleven species were mentioned exclusively by one of the communities; three species were mentioned by two of the communities; two species were shared by three of the communities; five species were of common medical use in four of the communities and only two species (Cuniculus paca and Salvator merianae) (Figure 3) were shared by all five communities, with similar preparation of the raw material extracted from the two species in all the communities.

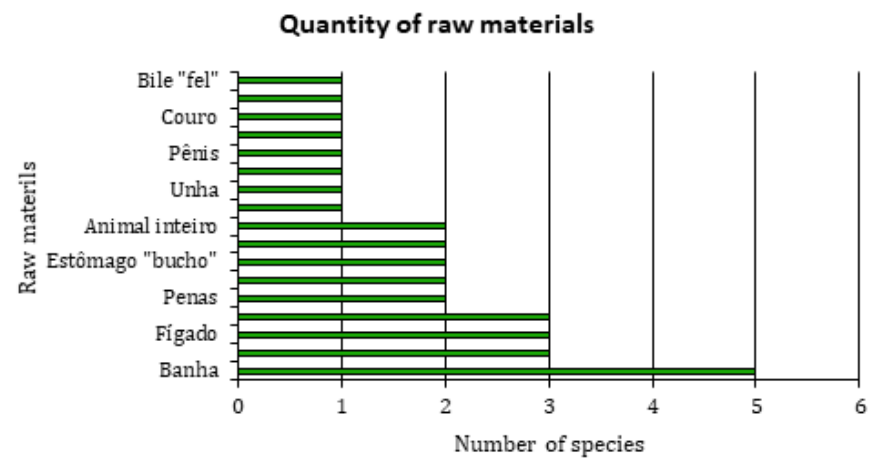

Figure 3. Quantity of raw materials from wild vertebrates used in traditional hunter farmer medicine in the region of Serra do Conduru State Park. Recorded: June/16 to June/17.
The zootherapeutic item cited with the greatest frequency was animal fat, a product that can be extracted from the following animals: Didelphis aurita, Caiman latirostris, Cuniculus paca, Boa constrictor and Salvator merianae. It is collected from five species that form part of the local prescription resource (Figure 4). Besides lard, other by-products such as claws, leather, fur, penis, tail, shell, feathers and liver are also used. The number of parts or products obtained from each animal varied from one to three; however, some species are used in their entirety, as is the case of the red-footed tortoise Geochelone carbonaria and bats (Order Chiroptera).

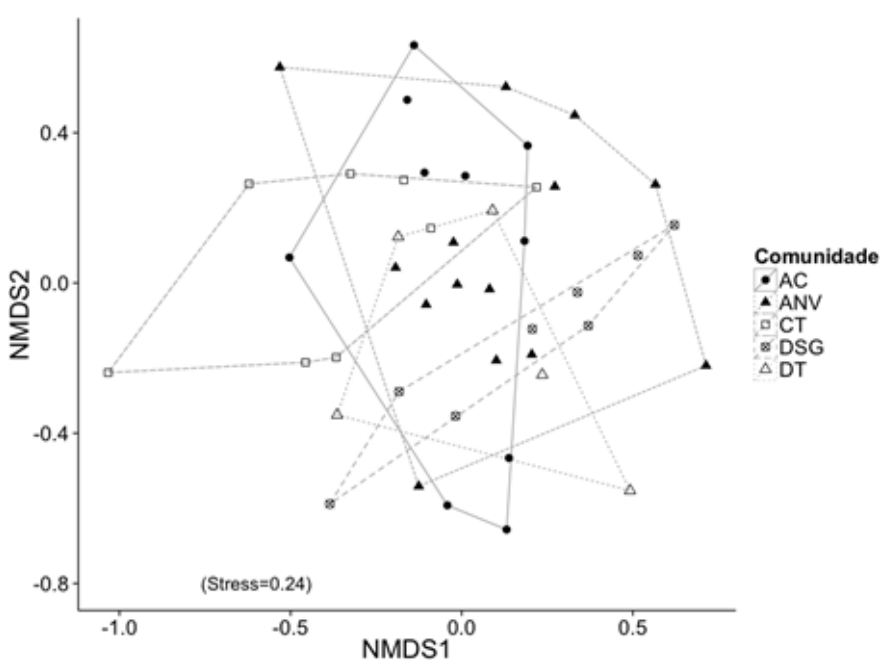

Figure 4. NMDS analysis showing the dissimilarity of the composition of wild animal species used as medicinal resources by hunter farmers in the five localities (communities) studied in the Serra do Conduru State Park region.

In the communities studied, animal by-products are roasted and processed into powder to be preserved or taken with warm water, teas, wine and/or other liquids, depending on the illness. Some parts, such as the liver of the crab-eating fox Cerdocyon thous are ingested directly, roasted or fried, without using seasoning or salt, locally termed "eating it bland." Some religious beliefs and rituals have also been mentioned: the red-footed tortoise, for example, is placed under the bed of people who experience back pain and the fur of sloth species is used to keep bad spirits away from people.

\section{Categorization of body systems}

Ten categories were classified for which therapeutic resources are recommended. Some diseases were listed in the category "indefinite diseases" due to characteristics that did not fit into the other categories (Table 2). Disorders related to the middle and inner ear, such as earache, were the most cited, with two therapeutic resources for their treatment: six- or nine-banded armadillo tails or tegu lard. Respiratory disorders (asthma, fatigue, cough and bronchitis) was the category with the second highest number of mentions, using eight therapeutic resources for treatment, followed by chronic diseases (diabetes), using only one zootherapy resource (paca "gall”) for its treatment (Table 2). 
Table 2. Categorization of body systems (ICD-10 2008).

\begin{tabular}{|c|c|c|c|c|}
\hline Body system & Treatable problems & $\begin{array}{c}\text { Number of } \\
\text { raw materials }\end{array}$ & $\begin{array}{c}\mathrm{N}^{0} \text { of } \\
\text { mentions }\end{array}$ & $\begin{array}{c}(\%) \\
\text { Mentions }\end{array}$ \\
\hline Chronic diseases & Diabetes & 1 & 22 & 14.8 \\
\hline Sexual dysfunction & Male impotence & 1 & 21 & 14.1 \\
\hline Skin and subcutaneous tissue diseases & $\begin{array}{l}\text { Pityriasis versicolor; spots on the skin; } \\
\text { wounds }\end{array}$ & 3 & 10 & 6.7 \\
\hline Neoplasia & Cancer & 2 & 2 & 1.3 \\
\hline Middle and inner ear disorders & Earache & 2 & 29 & 19.5 \\
\hline Circulatory system disorders & CVA*, hemorrhoids & 4 & 12 & 8 \\
\hline $\begin{array}{l}\text { Disorders of the teeth and their support } \\
\text { structures }\end{array}$ & Toothache & 1 & 4 & 2.7 \\
\hline Respiratory tract disorders & Asthma; fatigue; cough; bronchitis & 8 & 27 & 18.1 \\
\hline
\end{tabular}

Total mentions 149 100

Categorization of body systems in accordance with the International Statistical Classification of Diseases and Related Health Problems (ICD-10 2008) from which raw materials are used by hunter farmers in the PESC region for traditional medicine. Register: June/16 to June/17. (*) Cerebrovascular accident. Source: research data.

Some species of vertebrates mentioned are used for the treatment of more than one disease, such as tegu lard which is used to treat diseases like rheumatism, cough, back pain, Pityriasis versicolor and earache. On the other hand, some different species are indicated to treat the same disease, such as CVA, for which therapeutic resources from 6 species are used for treatment.

\section{Conservation status}

Of the recorded species, four are included in the endangered species categories established by the IUCN: Critically Endangered (CR), Endangered (EN), Vulnerable (VU) and Near Threatened (NT) (IUCN, 2014, Machado et al. 2008, Sema, 2017). The maned sloth Bradypus torquatus and the South American bushmaster Lachesis muta, which provide two and three raw materials for disease treatment respectively, are considered to be vulnerable in the wild. The solitary tinamou Tinamus solitarius, the feathers of which are used in the treatment of diseases, and the golden-headed lion tamarin Leontopithecus chrysomelas, the roasted liver of which is used for cancer treatment, are considered to be endangered (IUCN, 2014, Machado et al. 2008, Sema, 2017).

\section{Discussion}

\section{Species of medicinal use}

As in the present study, several publications have shown the importance of zootherapy in different rural communities in Brazil (Alves 2008, 2009, Alves \& Pereira-Filho 2007, Alves \& Rosa 2007a,b,c, Barboza et al. 2007, El-Kamali 2000, Kakati \& Douto 2002, Mahawar 2006, Vázquez 2006). For example, Branch \& Silva (1983) reported 33 species in Alter do Chão in the state of Pará; Begossi (1992) reported the use of 10 species on Ilha de Buzios in São Paulo. Marques (1995) noted the use of 56 species in Varzea de Marituba in the state of Alagoas, while Seixas \& Begossi (2001) reported 16 species used on Ilha Grande in Rio de Janeiro. Rodrigues (2006) reported the use of 29 species in Parque Nacional de Jau, Amazonas, while Alves \& Rosa (2006, 2007a,b) described the use of 74 species in Mamanguape in Paraiba, 57 species in Raposa in Maranhão, 54 species on Ilha do Marajo, and 46 species in Cajueiro da Praia in Piaui.

In the state of Bahia, there was a report of 23 species in the municipality of Remanso (Costa-Neto 2000a) and 34 species in the city of Tanquinho 34 (Costa-Neto 2000b). In larger sphere, CostaNeto (2004) pointed to the use of 180 animals in traditional medicine throughout the state. In the Atlantic Forest region of south Bahia specifically, the use of 14 species as medicinal resources by indigenous Tupinambá hunters from the district of Olivença (Ilhéus) has been described (Pereira \& Schiavetti 2010) and 11 species used by the residents of the Serra do Conduru State Park (Ribeiro \& Schiavetti 2009). This study demonstrates the importance of zootherapy for families in the Region Surrounding the PESC.

The fact that the mammals are the taxon with the highest number of species cited, followed by reptiles and birds corroborates the results obtained by previous authors, which show that, after fish, mammals and reptiles present the greatest number of species used as medicine in Brazil (Almeida \& Albuquerque 2002, Alves 2008, Begossi \& Braga 1992, Branch 1983, Silva et al. 2004). In line also with the catalogue of 584 species of animals of medicinal use in Latin America, which reveals that mammals are the group with most medicinal animals (Alves \& Alves 2011). As in this study, other research has indicated widespread use of the family Canidae in Latin America, Africa and Asia, and describe their use for treating 28 ailments, such as asthma, arthritis, and backache (Alves et al. 2010). 
In addition to their use for zootherapy, the use of wild species for food was also observed. This indicates another anthropic disturbance that acts in conjunction (synergistic effect) with medicinal use and entails an impact on the conservation of the vertebrates mentioned here. According to Alves and Rosa (2006) the multiple use of wild animals, which includes medicinal and food aspects, should be properly evaluated to understand the pressure that target species are subject to.

Historical studies indicate that the paca, species with the highest number of mentions for medicinal use in the study region, has suffered from the pressure of hunting for some time (Cardim 1925, Gândavo 1956, Silva 1898), in addition to studies published in several regions that describe the capture of the species in the last years (Canale 2012, Chiarello 2000, Freitas et al. 2005, Peres 1990, Peres \& Nascimento 2006, Varnhagen 1860). Fernandes-Ferreira and Alves (2014) in their work on the historical and current panorama of hunting in Brazil affirmed that the paca was cited by respondents from all biomes, allowing its identification as the preferred mammal for hunting in Brazil. In south Bahia the species was indicated the vertebrate that plays a major role in hunting for local communities (Castilho et al. 2018). However, due to their high demand, their population number may have been reduced in regions where they have been exploited excessively (Chiarello 2000, Deutsch 1990, Fernandes-Ferreira 2014). According to Alves and Souto (2010) in the Northeast region, mainly in the Caatinga Domain, the paca has already gone extinct in much of its original area of distribution. Fernandes-Ferreira (2011) documents reports of hunters from the Northeast stating that the species has been extinct locally for more than 40 years.

The tegu Salvator merianae was identified as the lizard of greatest importance to the zootherapeutic practices of the region, a fact also described by Alves et al. (2012) in a study carried out in two municipalities of Paraíba. The species was also cited by other researchers as a species of zootherapeutic use (Begossi 1992, Fernandes-Ferreira 2011, Klemens 1995, Oliveira et al. 2010, Souto et al. 2011). Fitzgerald (1994) states that lizards of this genus are also heavily hunted for consumption in Argentina, Paraguay, and parts of Bolivia. The review by Alves et al. (2008) describes that reptiles are among the most commonly used species in traditional folk medicine and have been since ancient times. In this aspect, the popularity of the use of tegu fat, a widespread natural medicine, has been the motive of one of the few studies on the clinical efficacy of animal products for medicinal purposes (Ferreira et al. 2010). The Bahia porcupine also referred to by other ethnozoological studies (Castilho 2013, 2018, Oliver 1991) as well as species Euphractus sexcinctus and Dasypus novemcinctus (Almeida \& Albuquerque 2002, Alves et al. 2012, Moura 2003).

The differences in medicinal use of species between the five surveyed communities is possibly related to the cultural beliefs rooted in each family. Traditionally, certain communities have the habit of using different species for the treatment of diseases and illnesses. This use is often restricted to only one or a few communities and is not widespread throughout the region. Another factor that may justify this dissimilarity is the varying frequency of occurrence and/ or abundance of species in each community, since they are spatially distant from one another and some are close to urban centers or more urbanized areas, which implies a smaller number of species in these areas. According to Alves et al (2007) and Alves (2009), the use of animal-based medicines is closely associated with local beliefs in different regions of Brazil. Different uses and combinations of hunting techniques may also influence composition of species. Some hunters may be more specialized or like to hunt only one species and others are more generalist, capturing more species.

Other authors have reported the use of similar raw materials as medicines in other Brazilian communities (Alves 2008, 2009, Costa-Neto 1999, 2004), which indicates that their use is widespread in the country. The preference for animal lard is common in zootherapy, described in different world reports (Castilo \& Ladio 2019, Filipov 1997, Bourdy et al. 2004; Martinez 2013, Medrano 2016, Moura \& Marques 2008) and in the northeastern Brazil (Alves et al. 2008, 2009, Costa-Neto, 1999, Ferreira et al. 2009a,b,c). Silva et al. (2004, 2010) indicated lard as the main by-product of wild animals for medicinal purposes in three public markets in Recife (PE) and in the semi-arid Paraíba. Ribeiro and Schiavetti (2009) also described the lard as the most commonly used animal part by the residents of the Serra do Conduru State Park, also located in southern Bahia state.

Medrano (2012) suggests that the fat holds the greatest potential of desirable attributes, and the possibility of transmission, amplifying this concept to include use/ingestion/contact with diferente animal parts. For Alves et al (2008), the wide utilization of lard can be attributed to the fact that the main medicinal animals utilized are vertebrates which have a large quantity of body fat. Another possible explanation for the marked use of body fat for medicinal purposes can be due its chemical composition. Body fat consists mainly of fatty acids, which have an extensive proven medicinal applicability (Ferreira et al. 2009a, 2010, 2011).

Just like in this research, links between popular beliefs and zootherapy have also been found in other Brazilian communities (Alves 2008,2009, Begossi \& Braga 1992, Branch 1983, Costa-Neto 1999, 2004, Marques 1995). The use of armadillo tail (Euphractus sexcinctus and Dasypus novemcinctus) to scratch and cure earaches has also been reported in the city of Santas Cruz do Capibaribe, state of Pernambuco (Alves et al. 2008) and in the city of Crato and Juazeiro do Norte, state of Ceará (Ferreira et al. 2009b). Whereas in Brazil, different animal species are used in magical-religious practices of Afro-Brazilian cults (Alves et al. 2009, Alves et al. 2010, Alves \& Pereira Filho 2007, Leo Neto et al. 2010, Leo Neto \& Alves 2010) in the context of rituals that emphasize the holistic nature of traditional medicine and that are designed to address spiritual, physical, and social-psychological problems (Alves \& Rosa 2010).

According to Zweber (2002), cultural issues are recognized as important components of the provision of health care services. The sociocultural and mythical-religious meaning of the species involves symbolic healing actions, or using animals as shamanistic auxiliaries that send and/or heal diseases by the transgression of taboos (Martínez $2010 \mathrm{a}, \mathrm{b})$. The zootherapy phenomenon is part of a complex medical system, which includes, among other folk practices of healing and disease prevention, rituals and magic prophylaxis, including mojos (patuás), scapulars (bentinhos), amulets, talismans, gestures and transfers (Araújo 1977, Vuoto 1999). The use of animals in native medicine transcends mere zootherapy (Vuoto 1999) and for being organized as cultural systems the use of animal substances must be understood from a cultural perspective (Costa-Neto 1999, 2004). 


\section{Categorization of body systems}

Wild animals and their parts and products are considered to be important ingredients for preparing curative and preventative medicines (Anyinam 1995). In the context of zootherapy, products of animal origin have been recorded as resources used in the treatment and attenuation of symptoms of various health problems in humans and domestic animals (Coutinho 2010). In this research, the zootherapy products are prescribed for the treatment of common diseases or illnesses in people's day-to-day lives, such as "fatigue" and back pain, however, some recommendations were made for more serious diseases, like CVA and cancer. To the hunters, the use of a particular raw material as a medicine in the region depends on the nature of the illness, and how people understand it culturally.

An analogous trend in relation to medicinal animals was found in cities in the north and northeast of Brazil (Alves \& Pereira-Filho 2007, Alves \& Rosa 2006, 2007a, Costa-Neto 1999, 2004). According to Alves and Rosa (Alves e Rosa 2007b), the two most frequent categories of use are gastrointestinal and respiratory diseases. Alves (2009) and Costa-Neto (2004) observed that the treatments most cited in Pernambuco and Bahia, respectively, are for the respiratory system, mainly related to the treatment of asthma. In total, 132 wild species used for the treatment of diseases related to the respiratory system were listed in all Brazilian territory (Alves \& Rosa 2012). Second Costa-Neto (2004) the animal-based remedies are frequently used to treat respiratory diseases (asthma, cough and bronchitis) (Costa-Neto 2004). Almeida and Albuquerque (2002) indicated that digestive problems represented the highest-use category, followed by respiratory diseases, diseases of the musculoskeletal system, and of connective tissue.

The literature shows that ethnobiological research on traditional medicines from natural resources is a valuable resource in the growing art of bioprospecting for compounds with pharmacological potential (Costa-Neto 1999). However, even with the high number of citations to illnesses treated with animal products commercialized in Brazil, there are few laboratory studies testing its efficacy (Ferreira et al. 2012). Some animals have been methodically tested by pharmaceutical companies as sources of drugs for modern medical science, with the discovery of active principles for the treatment of certain diseases (Kunin \& Lawton 1996). For Pieroni et al. (2002) the chemical constituents and pharmacological actions of medicinal products of animal origin are known and ethnopharmacological studies focused on this type of medicine are important in order to clarify their possible therapeutic usefulness.

For example, Ferreira et al. (2011) indicate that the body fat of Boa constrictor does not present a clinically relevant bacterial activity, but when combined with antibiotics, the fat demonstrated a significant synergistic activity. Similar results are reported to the decoction of the lizard Tropidurus hispidus and the termite Nasutitermes corniger. But et al. (1990) report the antifever activity of the preparations using the horn of Bos taurus. Murari et al. (2005) and Ferreira et al. (2010) report that extracts of Pavo cristatus and the body fat of Tupinambis merianae demonstrated anti-inflammatory activity. Tempone et al. (2008) showed that steroids from the skin of Rhinella jimi are active against leishmaniasis and trypanosomiasis.

Even with many species commercialized with medicinal uses in Brazil, studies about the improved biological activity of theses products are still preliminary and insufficient. Therefore care must be taken to use wild animals and their by-products for medicinal purposes. Smet (1991) draws attention to the fact that some sideeffects of traditional medicines have proven to be more severe than the disease that they are treating. Zootherapies recommended to treat a specific disease may not contain any active principle capable of producing such an effect or, if present, there may not be an effective concentration after preparation, leading to damage and health risks to those who believe in the efficacy of the product (Costa-Neto 2011). The development of more studies is necessary to understand, evaluate, and validate the traditional and medicinal knowledge associated with the use of animal products (Ferreira et al. 2012). Such considerations must be taken into account, further highlighting the need for clinical studies of traditional remedies (Alves \& Alves 2011).

There is also a concern for public health as some species of wild animals may be vectors of some infectious diseases. Diseases and infections that are naturally transmitted between vertebrate animals and humans are known as zoonoses (Bell et al. 1988, Krauss 2003, Van Vliet 2017) and have been known to affect human health throughout history (Kruse et al. 2004) and responsible for $75 \%$ of emerging infectious diseases (Chomel et al. 2007; Taylor et al. 2001). Several organs and tissues including bones and bile can be a source of Salmonella infection causing chronic diarrhoea and endotoxic shock. The possibility of transmission of other serious and widespread zoonoses such as tuberculosis or rabies should be considered whenever animal tissues from unknown sources are handled and used as remedies (Schnurrenberger \& Hubbert 1981). Another example deserving mention is Avian influenza (Influenza A) viruses; these are responsible for highly contagious acute illness in humans, pigs, horses, marine mammals and birds, occasionally resulting in devastating epidemics and pandemics (Bengis et al. 2004).

However, Ngokwey (1995) strengthens that the possibility of using several remedies for diseases, as quoted in this research, is an adaptation to the availability/accessibility of the animals that can be used and that depending on this factor, it is possible to use several remedies for the same disease. The use of various zootherapeutic resources to treat the same disease demonstrates a utilitarian redundancy, a model proposed by Albuquerque and Oliveira. (Albuquerque \& Oliveira 2007). According to these authors, the idea of utilitarian redundancy is based on the theory of ecological redundancy, the notion of functional redundancy relies on the presumption that some species are utilized for the treatment of more than one disease and/or symptom, such that the inclusion of more than one species within a disease category can be a mechanism of reducing the impact on the animals sold for medicinal purposes (Albuquerque \& Oliveira 2007).

Ferreira et al. (2009) indicated the use of more than one species for the treatment of some diseases in public markets in the cities of Crato and Juazeiro do Norte, Ceará state, Brazil. The fat from C. durissus, for example, is used to treat rheumatism, osteoporosis, leprosy, back-aches, ear-aches, and fissures on soles of the feet; while the rattle from this same snake is used in simpatias. The fat of T. merianae is used to treat rheumatism, inflammations, fissures on sole of the feet, and ear-aches (Ferreira et al. 2009).

\section{Conservation status}

Studies have estimated that, respectively, $25 \%$ and $53 \%$ of canids and reptiles used in zootherapy are listed in some degree of extinction 
threat according to the IUCN (Alves et al. 2010, Alves et al 2008). Costa-Neto (1999) estimated that $30 \%$ of all animal pharmacopoeia in northeastern Brazil is threatened with extinction. With regards to conservation, the use of traditional animal-based medicines can threaten biodiversity (Costa-Neto 2011). As argued by Martínez and collaborators (2013), many species play a key role in local ecosystems and their reduction and disappearance would cause environmental changes. For Marques (1997), the medical potential of the Brazilian fauna and flora allows for exhaustion or extinction of species due to their overexploitation. However, although medical use is relevant because it implies additional pressure on critical animal populations, it should be emphasized that many factors affect vertebrate populations in the PESC region, such as hunting for food and commercial purposes.

In this case, zootherapy should be considered along with other anthropogenic pressures, such as loss of habitat, human activities such as agriculture, domestic animal husbandry, and subsistence hunting (Alves 2009, Leal 2005). It is also necessary to consider where these species are being used, in the case of this study these are environmentally protected areas where it is prohibited to hunt without authorization from the competent organs, regardless of the purpose.

According to Andriguetto-Filho and collaborators (1998), zootherapeutic practices, if properly managed, can be compatible with environmental conservation programs, where the use of natural resources can occur in such a way that human needs and biodiversity protection are guaranteed. This demonstrates the need for further studies to determine the extent to which medicinal use in the region may be causing problems for local vertebrate fauna. Therefore, it is necessary to understand the biology and ecology of species commonly used as remedies to better evaluate the impacts of this use on populations of local species (Alves et al. 2007). The medicinal value of species represents an important link between human society and biodiversity that therefore needs to be recognized in efforts aimed at sustainable use of ecosystems (Alves et al. 2009).

\section{Final Considerations}

The results obtained showed that hunter-farmers in the area surrounding the PESC traditionally use wild vertebrates as a medicinal resource in the treatment of diseases and illnesses that are culturally recognized in the communities studied. A total of 23 species were identified from which 17 raw materials are obtained for the treatment of 19 local illnesses. Some of these species are endangered.

Although two species are commonly used for medicinal purposes in all the communities, the research demonstrated a dissimilarity regarding the composition of the species with cultural use in each community. This can also be justified by the frequency and abundance of the species, hunting techniques and their combinations, and the influence of the local culture.

Zootherapy products are used to treat diseases common in the region, such as problems in the skeletal system, middle and inner ear disorders, and circulatory and respiratory system disorders. However, additional studies are needed to broaden knowledge of other species that may exist in the region and which have an important cultural value to families, as well as to evaluate in an ecological context the implications that can result from the uncontrolled use of these species in traditional medicine.

\section{Acknowledgements}

We would like to thank the farmers in the area surrounding the PESC, for their trust and contributions during the research. The Graduate Program in Zoology (PPGZOO). The Coordination of Improvement of Higher Education Personnel - Brazil (CAPES) - Financing Code 001, for granting the scholarship. CNPq for the productivity grant and CAPES, for the Visiting Overseas Professor scholarship to the author AS. Iuri Dias, for the elaboration of the map.

\section{Author Contributions}

Joanison Vicente dos Santos Teixeira: substantial contribution to the design and design of the work; contribution to the acquisition of data; contribution in the analysis and interpretation of data; contribution in the writing of the work.

Jade Santos: contribution to the acquisition of data; contribution in the writing of the work.

Deyna Hulda Arêas Guanaes: contribution to the acquisition of data; contribution in the writing of the work.

Wesley Duarte da Rocha: contribution in the analysis and interpretation of data.

Alexandre Schiavetti: contribution in the writing of the work; contribution in the critical review adding intellectual contente.

\section{Conflicts of Interest}

The authors declares that they have no conflict of interest related to the publication of this manuscript.

\section{Availability of Data and Material}

The data used to support the fndings of our study are available from the correspondences upon request.

\section{References}

ADEOLA, M.O. 1992. Importance of wild Animals and their parts in the culture, religious festivals, and traditional medicine, of Nigeria. Environmental Conservation, 19(2):125-134.

ALBUQUERQUE, U.P \& OLIVEIRA, R.F. 2007. Is the use-impact on native caatinga species in Brazil reduced by the high species richness of medicinal plants?" Journal of Ethnopharmacology, vol. 113, no. 1, pp. 156-170.

ALBUQUERQUE, U.P. \& PAIVA. R.F. 2004. Métodos e técnicas na pesquisa etnobotânica Recife: Editora Livro Rápido/NUPEEA.

ALBUQUERQUE, U.P., LUCENA, R.P. \& ALENCAR, N.L. 2008. Métodos e técnicas para a Pesquisa Etnobotânica. 2. ed. Recife: NUPEEA.

ALGER, K. \& CALDAS, M. 1994. The declining Cocoa economy and the Atlantic Forest of Southern Bahia, Brazil: Conservation attitudes of Cocoa planters. The Environmentalist 14(2):107-119.

ALMEIDA, A. V. 2007. Zooterapia indígena brasileira no século XVI nas obras de Guilherme Piso, Georg Marcgrave e Johannes de Laet. Sitientibus ser Ci Biol. 7(3):261-272.

ALMEIDA, C.F.R. \& ALBUQUERQUE, U.P. 2002. Uso e conservação de plantas e animais medicinais no estado de Pernambuco (Nordeste do Brasil): um estudo de caso. Interciência. 27(6):276-285.

ALONSO-CASTRO A. et al. 2011. Zootherapeutic practices in Aquismón, San Luis Potosí, México. Journal of Ethnopharmacology 138: 233-237.

ALVES, R. R. 2009. Fauna used in popular medicine in Northeast Brazil,’ Journal of Ethnobiology and Ethnomedicine, vol. 5, article 1. 
ALVES, R.R. \& ROSA, I.L. 2005. Why study the use of animal products in traditional medicines? J Ethnobiol Ethnomed, 1:1-5.

ALVES, R.R. 2008a. Animal-based remedies as complementary medicine in Brazil. Res Complement Med, 15:226-227.

ALVES, R.R. et al. 2008b. Animal-based remedies as complementary medicines in Santa Cruz do Capibaribe, Brazil. BMC Complement Altern Med, 8:44.

ALVES, R.R. et al. 2009. Commercialization of animal-derived remedies as complementary medicine in the semi-arid region of Northeastern Brazil. Journal of Ethnopharmacology 124:600-608.

ALVES, R.R., ROSA, I.L. \& SANTANA, G.G. 2007. The role of animal-derived remedies as complementary medicine in Brazil. BioScience, 57:11.

ALVES, R.R.N \& ROSA, I.L. 2005. Why study the use of animal products in traditional medicines? Journal of Ethnobiology and Ethnomedicine. 1: 1-5.

ALVES, R.R.N et al. 2012. Animals for the Gods: Magical and Religious Faunal Use and Trade in Brazil. Human Ecology, vol. 40 p.751-780.

ALVES, R.R.N. \& ALVES, H.N. 2011. The faunal drugstore: Animalbased remedies used in traditional medicines in Latin America. Journal of Ethnobiology and Ethnomedicine 7:99.

ALVES, R.R.N. \& PEREIRA FILHO G.A. 2007. Commercialization and use of snakes in North and Northeastern Brazil: implications for conservation and management. Biodivers Conserv, 16:969-985.

ALVES, R.R.N. \& PEREIRA-FILHO, G.A. 2007. Commercialization and use of snakes in North and Northeastern Brazil: implications for conservation and management. Biodvers Conserva, 16: 969-985.

ALVES, R.R.N. \& ROSA, I.L. 2006. From Cnidarians to mammals: The use of animals as remedies in fishing communities in NE Brazil. Journal of Ethnopharmacology, n.107, p.259-276.

ALVES, R.R.N. \& ROSA, I.L. 2007a. Zootherapeutic practices among fishing communities in North and Northeast Brazil: A comparison. J Ethnopharmacol, v. 111, p.82-103.

ALVES, R.R.N. \& ROSA, I.L. 2007b. Zootherapy goes to town: The use of animal-based remedies in urban areas of NE and $\mathrm{N}$ Brazil. J Ethnopharmacol, v. 113, p. 541-555.

ALVES, R.R.N. \& ROSA, I.L. 2007c. Biodiversity, traditional medicine and public health: where do they meet? J Ethnobiol Ethnomedicine, v. 3, p. 9.

ALVES, R.R.N. \& ROSA, I.L. 2012. Animals in Traditional Folk Medicine. Implications for Conservation. Berlin Heidelberg. Springer.

ALVES, R.R.N. \& SANTANA, G.G. 2008. Use and commercialization of Podocnemis expansa (Schweiger 1812) (Testudines: Podocnemididae) for medicinal purposes in two communities in North of Brazil. Journal of Ethnobiology and Ethnomedicine, 4(3):6

ALVES, R.R.N. \& SOUTO, W.M.S. 2010. Etnozoologia: conceitos, considerações históricas e importância. In: ALVES, R.R.N., SOUTO, W.M.S. \& MOURÃO, J.S. (Eds.). A Etnozoologia no Brasil: Importância, Status atual e Perspectivas. Volume 7. 1 edition. Recife, PE, Brazil. NUPEEA.19-40.

ALVES, R.R.N. 2008. Animal-Based Remedies as Complementary Medicine in Brazil. Forsch Komplementarmed/Research in Complement Med, v.15, p. 226-227.

ALVES, R.R.N. 2009. Fauna used in popular medicine in Northeast Brazil. J Ethnobiol Ethnomedicine, v. 5, p. 1-30.

ALVES, R.R.N. et al. 2009. Hunting strategies used in the semi-arid region of northeastern Brazil. Journal of Ethnobiology and Ethnomedicine, 5:1-50.

ALVES, R.R.N. et al. 2011. Animal- Based Remedies as Complementary Medicines in the Semi-Arid Region of Northeastern Brazil. Evidence-Based Complementary and Alternative Medicine doi:10.1093/ecam/nep134.

ALVES, R.R.N. et al. 2013. Medicine from the wild: an overview of the use and trade of animal products in traditional medicines. In: ALVES, R.R.N., ROSA, I.L (eds.). Animals in traditional folk medicine, 1st edn. Springer, Berlin, pp 25-42. doi:10.1007/978-3-642-29026-8_3.

ALVES, R.R.N., GONÇALVES, M.B.R. \& VIEIRA W.L.S. 2012. Caça, uso e conservação de vertebrados no semiárido Brasileiro. Tropical Conservation Science, v. 5, p. 396-416.
ALVES, R.R.N., ROSA, I.L. \& SANTANA, G.G. 2007. The Role of Animalderived Remedies as Complementary Medicine in Brazil. BioScience, 57(11): 949955

ALVES, R.R.N., VIEIRA, W.L.S. \& SANTANA, G.G. 2008. Reptiles used in traditional folk medicine: conservation implications. Biodiversity and Conservation 17:2037- 2049.

ANAGELETTI, L.R. et al. 1992. Healing rituals and sacred serpents. Lancet. 340:223-225.

ANDERSON, M.J. 2005. Permanova: a fortran computer program for permutacional multivariate analysis of variance. In: Departament of Statistc, University of Auckland, New Zealand. pp. 1-24.

ANDRIGUETTO-FILHO, J.M., KRÜGER, A.C. \& LANGE, M.B. 1998 Caça, biodiversidade e gestão ambiental na Área de Proteção Ambiental de Guaraqueçaba, Paraná, Brasil. Biotemas, 11:133-156.

ANYINAM, C. 1995. Ecology and ethnomedicine: exploring links between current environmental crisis and indigenous medical practices. Social Science \& Medicine 40, 321-329.

APAZA, L. et al. 2003. Markets and the use of wild animals for traditional medicine: a case study among the Tsimane' Amerindians of the Bolivian rain forest. J Ethnobiol 2003, 23:47-64.

ARAÚJO, A.M. 1977. Medicina rústica. São Paulo: Companhia Editora Nacional.

ARGÔLO, A.J.S. 2004. As serpentes dos cacauais do sudeste da Bahia. Editus, Ilhéus, Bahia.

BAHIA (Estado). 2017. Portaria $\mathrm{n}^{\circ} 37$ de 15 de agosto de 2017. Torna pública a lista oficial das espécies da fauna ameaçadas de extinção do estado da Bahia. Diário Oficial do Estado da Bahia. 15 de ago de 2017.

BAILEY, K.D. 1982. Methods of social research. 2 ed. McMillan Publishers, New York.

BARBOZA, R.R.D., SOUTO, W.M.S. \& MOURÃO, J.S. 2007. The use of zootherapeutics in folk veterinary medicine em the district of Cubati, Paraíba State, Brazil. Journal of Ethnobiology and Ethnomedicine, v. 3, n. 32.

BEGOSSI, A. \& BRAGA, F.M.S. 1992. Foods Taboos and Folk Medicine among Fishermem from the Tocantins River (Brazil). Amazonia, 12:101-118.

BEGOSSI, A. 1992. Food taboos at Búzios Island (SE Brazil): their significance and relation to folk medicine. J. Ethnobiol., 12: 117-139.

BELL, J.C., PALMER, S.R. \& PAYNE, J.M. 1988. The zoonoses (infections transmitted from animals to man). 1 ed. Arnold, London.

BENGIS, R.G. et al. 2004. The role of wildlife in emerging and re-emerging zoonoses. Rev. sci. tech. Off. int. Epiz. 23:497-511.

BOURDY, G., CHAVEZ DE MICHEL, L.R. \& ROCA-COULTHARD, A. 2004 Pharmacopoeia in a shamanistic society: the Izoceño-Guaraní (Bolivian Chaco). Journal of Ethnopharmacology 91:189-208.

BRANCH, L. \& SILVA, M.F. 1983. Folk medicine in Alter do Chão, Pará, Brasil. Acta Amazônica, 13, 737-797.

BUT, P.P., LUNG, L. \& TAM, Y. 1990. Ethnopharmacology of rhinoceros horn. I: antipyretic effects of rhinoceros horn and other animal horns," Journal of Ethnopharmacology, vol. 30, no. 2, pp. 157-168.

CALL, E. 2006. Mending the Web of Life: Chinese Medicine and Species Conservation. 1 ed. International Fund for Animal Welfare, Massachusetts.

CANALE, G.R. et al. 2012. Pervasive defaunation of forest remnants in a tropical biodiversity hotspot. PloS one, 7(8), e41671.

CARDIM, F. 1925. Tratado da terra e gente do Brasil. Rio de Janeiro, J. Leite e Cia.

CASTILHO, L. \& LADIO, A. 2019. Zootherapy and rural livestock farmers in semiarid Patagonia: the transfer of animal aptitudes for health. Ethnobiology and Conservation, 8:2. doi:10.15451/ec2019018.02124

CASTILHO, L.C et al. 2013. The thin-spined porcupine, Chaetomys subspinosus (Rodentia: Erethizontidae), within protected areas in the Atlantic Forest, Brazil: local knowledge and threats. Tropical Conservation Science, vol.6 (6):796-810. 
CASTILHO, L.C et al. 2018. Attitudes and Behaviors of Rural Residents Toward Different Motivations for Hunting and Deforestation in Protected Areas of the Northeastern Atlantic Forest, Brazil. Tropical Conservation Science, Volume 11: 1-14.

CHIARELLO, A.G. 2000. Influência da caça ilegal sobre mamíferos e aves das matas de tabuleiro do norte do estado do Espírito Santo. Boletim do Museu de Biologia Mello Leitão, 11(12), 229-247.

CHOMEL, B.B., BELOTTO, A. \& MESLIN, F.X. 2007. Wildlife, exotic pets, and emerging zoonoses. Emerging Infectious Diseases 13:6-11.

CID-10. Classificação Estatística Internacional de Doenças e Problemas Relacionados à Saúde. 2008. Décima Revisão. Volume I. Disponível em: http://www.datasus.gov.br/cid10/v2008/webhelp/cid10.htm. Acesso em 15 de jun. de 2017.

COMITÊ BRASILEIRO DE REGISTROS ORNITOLÓGICOS. 2014. Listas das aves do Brasil. 11 ed.

CORDEIRO, P.H.C. 2003. Inventário de aves em remanescentes florestais de Mata atlântica no sul da Bahia, lista das espécies observadas. In: PRADO P. I. et al. (Orgs.). Corredor de Biodiversidade da Mata Atlântica do Sul da Bahia, Instituto de Estudos Sócio-Ambientais do Sul da Bahia e Conservation International do Brasil.

COSTA, R.P.C. \& SILVA, W.G. 1993. Medicina popular da Amazônia brasileira I: identificação dos ácidos graxos e triglicerídeos da banha da cobra sucuriju (Eunnects murinus). Revista da Universidade do Amazonas (Série Ciências da Saúde).

COSTA-NETO, E.M. \& OLIVEIRA, M.V.M. 2000. Cockroach is good for asthma: zootherapeutic practices in Northeastern Brazil. Hum Ecol Rev, 7(2):41-51.

COSTA-NETO, E.M. 1999. Barata é um Santo Remédio: introducão a zooterapia popular no Estado da Bahia. Editora Universitáaria da UEFS, Feira de Santana, p. 103.

COSTA-NETO, E.M. 1999. Healing with animals in Feira de Santana city, Bahia, Brazil. Journal of Ethnopharmacolgy, 65, 225-230.

COSTA-NETO, E.M. 2000. Conhecimento e usos tradicionais de recursos faunísticos por uma comunidade afro-brasileira. Resultados preliminares. Interciência, 25(9):423-431.

COSTA-NETO, E.M. 2002. The use of insects in folk medicine in the state of Bahia, Northeastern Brazil, with notes on insects reported elsewhere in Brazilian folk medicine. Hum Ecol Ver 2002, 30(2):245-263.

COSTA-NETO, E.M. 2004. Implications and applications of folk zootherapy in the state of Bahia, Northeastern Brazil. Sust Dev., 12:161-174.

COSTA-NETO, E.M. 2011. A zooterapia popular no Estado da Bahia: registro de novas espécies animais utilizadas como recursos medicinais. Ciência \& Saúde Coletiva, 16(Supl. 1):1639-1650.

COUTINHO, H.D.M. 2010. Validação de atividades biológicas e isolamento de produtos naturais de origem animal. In: COSTA-NETO, E.M. \& ALVES, R.R.N. (Org.). Zooterapia: os animais na medicina popular brasileira. Recife: NUPEEA, p. 189-197.

De Smet PAGM: Is there any danger in using traditional remedies? J Ethnopharmacol 1991, 32:43-50.

DEUTSCH, L.A. \& PUGLIA, L.R.R. 1990. Os animais silvestres: proteção, doenças e manejo. 2 ed. Globo, São Paulo.

EL-KAMALI, H.H. 2000. Folk medicinal use of some animal products in Central Sudan. J Ethnopharmacol. v. 72, p.279-282.

ENCARNAÇÃO, A.M.V. 2001. Ocupação temporal e espacial e aspectos da predação de frutos do cacaueiro (Theobroma cacao L.) por pequenos mamíferos (Mammalia) em cacauais e mata atlântica no sudeste da Bahia Dissertação de mestrado, Universidade Estadual de Santa Cruz, Ilhéus, Bahia, Brasil.

ENRIQUEZ VAZQUEZ, P. et al. 2006. Uso medicinal de la fauna silvestre en los altos de Chiapas, México. Interciencia 31:491-499.

FERNANDES-FERREIRA, H. \& ALVES, R.R.N. 2014. Legislação e mídia envolvendo a caça de animais silvestres no Brasil, uma perspectiva histórica e socioambiental. Revista Gaia Scientia, 8(1).
FERNANDES-FERREIRA, H. 2011. Atividades cinegéticas em um Brejo de Altitude no Nordeste do Brasil: Etnozoologia e Conservação. Dissertação de mestrado, Universidade Federal da Paraíba.

FERREIRA, F.S. et al. 2009a. Animal-based folk remedies sold in public markets in Crato and Juazeiro do Norte, Ceará, Brazil. BMC Complement Altern Med, 9:17.

FERREIRA, F.S. et al. 2009b. Is the body fat of the lizard Tupinambis merianae effective against bacterial infections?" Journal of Ethnopharmacology, vol. 126, no. 2, pp. 233-237.

FERREIRA, F.S. et al. 2009c. Zootherapeutics utilized by residents of the community Poço Dantas, Crato-CE, Brazil. Journal of Ethnobiology and Ethnomedicine, 5:21 doi:10.1186/1746-4269-5-21

FERREIRA, F.S. et al. 2010. Topical anti-inflammatory activity of body fat from the lizard Tupinambis merianae. Journal of Ethnopharmacology 130:514-520.

FERREIRA, F.S. et al. 2011. Potentiation of aminoglycoside antibiotic activity using the body fat from the snake Boa constrictor," Revista Brasileira Farmacognosia, vol. 21, no. 3, pp. 503-509.

FERREIRA, F.S. et al. 2012. The Trade in Medicinal Animals in Northeastern Brazil. Evidence-Based Complementary and Alternative Medicine. Volume 2012, Article ID 126938, 20 pages. doi:10.1155/2012/126938

FIGUEIREDO, N. 1994. Os bichos curam: os animais na medicina de folk em Belém do Pará. Bol. Mus. Paraense Emílio Goeldi. Série Antropologia. 10:75-91.

FITZGERALD, L.A. 1994. Tupinambis lizards and people: a sustainable use approach to conservation and development. Conservation Biology 8:12-15.

FREITAS, F.O., MOREIRA, J.R. \& FREITAS, J. Z. F. 2005. Tradição cultural como diferenciador da dieta a base animal de duas etnias indígenas. 1 ed. Embrapa Recursos Genéticos e Biotecnologia, Brasília, 9 p. (Comunicado Técnico 126).

GÂNDAVO, P.D.M. 1956. Historia da prouincia sãcta Cruz a que vulgarmente chamamos Brasil feita por Pero de Magalhães de Gandavo, dirigida ao muito Ills. Sñor Dom Leonis Pra governador que foy de Malaca e das mais partes do Sul da India. Lisboa, Officina de Antonio Gonsalvez.

GÓMEZ-ULLA, A.A. 1983. Los animales en la antigua formulación magistral. Offarm, 2(2): 75-82.

HAYS, T.E. 1976. An Empirical Method for the Identification of Covert Categories in Ethnobiology. American Ethnologist 3:489-507.

HUNTINGTON H.P. 2000. Using Traditional Ecological Knowledge in Science: Methods and Applications. Ecological Applications 10:1270-1274.

INSTITUTO YNAMATA. 2008. Instituto Floresta Viva. Diagnóstico Participativo de Serra Grande. Serra Grande. 132p.

IUCN: Red List of Threatened Species. 2014. Disponível em: http://www. iucnredlist.org. Acesso em 18 de julho de 2017.

JACOBO-SALCEDO, M.R., ALONSO-CASTRO, A.J. \& ZARATEMARTÍNEZ, A. 2010. Folk medicinal use of fauna in Mapimi, Durango, México. Journal of Ethnopharmacology 122:902-906.

KAKATI, L.N. \& DOULO, V. 2002. Indigenous knowledge system of zootherapeutic use by chakhesang tribe of Nagaland, India. J Hum Ecol. v. 13, p. $419-42$.

KAKATI, L.N., AO, B. \& DOULO, V. 2006. Indigenous knowledge of zootherapeutic use of vertebrate origin by the ao Tribe of Nagaland. J Hum Ecol, 19(3):163-167.

KIKUCHI. R, 2012. Captive bears in human-animal welfare conflict: a case study of bile extraction on Asias bear farms. J Agric Environ Ethics 25:55-77. doi:10.1007/s10806-010-9290-2

KLEMENS, M.W. \& THORBJARNARSON, J.B. 1995. Reptiles as a food resource. Biodiver Conserv, 4: 281-298.

KRAUSS, H. 2003. Zoonoses: infectious diseases transmissible from animals to humans. 1 ed. Amer Society for Microbiology Press.

KRUSE, H., KIRKEMO. A.M. \& HANDELAND, K. 2004. Wildlife as source of zoonotic infections. Emerging Infectious Diseases 10:2067-2072. 
KUNIN, W.E. \& LAWTON, J.H. 1996. Does biodiversity matter? Evaluating the case for conserving species. In: GASTON K.J. (Ed.). Biodiversity: a biology of numbers and differences. Oxford, UK: Blackwell Science, p. 283-308.

LAGES-FILHO, J. 1934. A medicina popular em Alagoas. Separata dos Archivos do Instituto Nina Rodrigues. 3(1 e 2).

LEAL, I.R. et al. 2005. Changing the Course of Biodiversity Conservation in the Caatinga of Northeastern Brazil. Conserv Biol, v. 19, p. 701-706.

LEAL-GALINDO, C. \& CÂMARA, I.G. 2003. Atlantic forest hotspots status: an overview. In: LEAL- GALINDO, C. \& CÂMARA, I. G (Eds.). The Atlantic Forest of South America: biodiversity status, threats, and outlook. CENTER FOR APPLIED BIODIVERSITY SCIENCE AND ISLAND PRESS, WASHINGTON, DC.

LEO NETO, N,A, BROOKS, S.E \& ALVES, R.R.N. 2009. From Eshu to Obatala: animals used in sacrificial rituals at Candomble "terreiros" in Brazil. Journal of Ethnobiology and Ethnomedicine, 5:1-23.

LÉO NETO, N.A. \& ALVES, R.R.N. 2010. "Sangue e música": animais utilizados em rituais de sacrifício em terreiros de Candomblé. In: ALVES, R.R.N., SOUTO, W.M.S. \& MOURÃO, J.S (Eds.). A Etnozoologia no Brasil: Importância, Status atual e Perspectivas. Volume 7. 1 edition. Recife, PE, Brazil: NUPEEA;0:495-512.

LEV, E. 2003. Traditional healing with animals (zootherapy): medieval to present-day Levantine practice. Journal of Ethnopharmacology. 85(1): 107-118.

LEV, E. 2006. Ethno-diversity within current ethno-pharmacology as part of Israeli traditional medicine - A review. J Ethnobiol Ethnomed, 2:4.

LO CURTO, A. 1990. Gli animali che curano secondo la medicina indigena dell'Amazzonia. Roma: Universale Electa/Gallimard.

LOBÃO, E.S.P. \& NOGUEIRA-FILHO, S.L.G. 2011. Human-wildlife Conflicts in the Brazilian Atlantic Forest. Suiform Soundings 10(2):14-22.

MACHADO, A.B.M., DRUMOND, G.M. \& PAGLIA, A.P (Ed.). 2008. Livro vermelho da fauna brasileira ameaçada de extinção. Vol. 1. Brasília: ICMBio.

MAHAWAR, M.M \& JAROLI. D.P. 2006. Animals and their products utilized as medicines by the inhabitants surrounding the Ranthambhore National Park, India. J Ethnobiol Ethnomedicine, v. 2, p. 5.

MAHAWAR, M.M \& JAROLI. D.P. 2007. Traditional knowledge on zootherapeutic uses by the Saharia tribe of Rajasthan, India. J Ethnobiol Ethnomed 2007, 3:25.

MARQUES, J.G.W. 1991. Aspectos Ecológicos na Etnoictiologia dos Pescadores do Complexo Estuarino-Lagunar Mundaú-Manguaba, Alagoas. Tese (Doutorado em Ecologia) - Universidade Estadual de Campinas, Campinas.

MARQUES, J.G.W. 1995. Pescando pescadores: etnoecologia abrangente no baixo São Francisco Alagoano. São Paulo: NUPAUB/USP.

MARQUES, J.G.W. 1997. Fauna medicinal: Recurso do ambiente ou ameaça à biodiversidade? Mutum 1, 4 .

MARTÍNEZ, G.J. 2010a. Los remedios naturales en la prevención y cuidado de la salud oral de los tobas del Chaco Central (Argentina). Boletín Latinoamericano y del Caribe de Plantas Medicinales y Aromáticas. BLACPMA 9:109-122.

MARTÍNEZ, G.J. 2010b. Enfermedad y entidades anímicas del entorno natural: etiologías religioso-rituales y espacio-ambientales entre los tobas del Chaco Central, Argentina. AIBR Revista de Antropología Iberoamericana 5:189-221.

MARTÍNEZ, G.J. 2013. Use of fauna in the traditional medicine of native Toba (qom) from the Argentine Gran Chaco region: na ethnozoological and conservationist approach. Ethnobiology and Conservation 2(2):1-43.

MARTINI, A.M.Z. et al. 2007. A hot-point within a hot-spot: a high diversity site in Brazil's Atlantic Forest. Biodiversity and Conservation, v 16, p. 3111-3128.

MEDRANO, M.C. 2012. Etnozoología, usos y abusos de los cuestionarios. Papeles de trabajo Centro de Estudios Interdisciplinarios em Etnolingüística y Antropología SocioCultural 23:59-81.

MILÁN, P. 2011. Zootherapeutic practices in Aquismón, San Luis Potosí, México. Journal of Ethnopharmacology 138: 233-237.
MINISTÉRIO DO MEIO AMBIENTE - MMA. 2000. Avaliação e ações prioritárias para a conservação da biodiversidade da mata atlântica e campos sulinos. Brasília: MMA/SBF.

MINISTÉRIO DO MEIO AMBIENTE - MMA. 2004. Programa Piloto para a Proteção das Florestas Tropicais-PPG7-Projeto Corredores Ecológicos, Bahia (Estado), Secretaria de Meio Ambiente e Recursos AmbientaisSEMARH, Centro de Recursos Ambientais-CRA, Superintendência de Desenvolvimento Florestal e Unidades de Conservação-SFC. Revisão do Zoneamento Ecológico-Econômico: APA Costa de Itacaré-Serra Grande. Instituto de Estudos Socioambientais do Sul da Bahia-IESB, Conservação Internacional do Brasil-CI, Ilhéus, Bahia, Brasil.

MOURA, F.B.P. \& Marques, J.G.W. 2008. Zooterapia popular na Chapada Diamantina: uma medicina incidental? Ciência and Saúde Coletiva 13:2179-2188.

MOURA, R.T. 2003. Distribuição e ocorrência de mamíferos na Mata Attântica do sul da Bahia. In: PRADO, P. I. et al. (Orgs.). Corredor de biodiversidade da Mata Atlântica do sul da Bahia. Publicação em CD-ROM, Ilhéus, IESB/ $\mathrm{CI} / \mathrm{CABS} / \mathrm{UFMG} / \mathrm{UNICAMP}$.

MURARI, S.K. et al. 2005. Use of Pavo cristatus feather extract for the better management of snakebites: neutralization of inflammatory reactions," Journal of Ethnopharmacology, vol. 99, no. 2, pp. 229-237.

NEGI, C.S. \& PALYAL. V.S. 2007. Traditional uses of animal and animal products in medicine and rituals by the Shoka Tribes of District Pithoragarh, Uttaranchal, India. Ethno-Med, 1(1):47-54.

NGOKWEY, N. 1995. Home remedies and doctors "remedies in Feira (Brazil). Soc Sci Med. v. 40, p. 1141-1153.

OKSANEN, J. et al. 2011. Vegan: community ecology package. Version 1.1711. Disponível em: http://vegan.r-forge.r-project.org. Acesso em 12 de jul. de 2017

OLIVEIRA, E.S. et al. 2010. The medicinal animal markets in the metropolitan region of Natal City, northeastern Brazil. Journal of Ethnopharmacology, 130: 54-60.

OLIVER, W.L.R. \& SANTOS, I.B. 1991. Threatened endemic mammals of the Atlantic forest region of south-east Brazil. Jersey Wildlife Preservation Trust, Special Scien. Rep., 4:1-126. il.

PAGLiA, A. P. et al. 2012. Lista Anotada dos Mamíferos do Brasil: 2 ed. Conservation international. Occasional Paper n 6.

PEREIRA, J.P.R. \& SCHIAVETTI, A. 2010. Conhecimentos e usos da fauna cinegética pelos caçadores indígenas "Tupinambá de Olivença" (Bahia). Biota Neotropica, 10, 175-183.

PERES, C.A. \& NASCIMENTO, H. 2006. Impact of game hunting by the Kayapo of south-eastern Amazonia, Implications for wildlife conservation in tropical forest indigenous reserves. Biodiversity and Conservation 15, 2627-2653.

PERES, C.A. 1990. Effects of hunting on western Amazonian primate communities. Biological Conservation, 54(1), 47-59.

PIERONI A. et al. 2002. Ethnopharmacy of the ethnic Albanians (Arbëreshë) of northern Basilicata, Italy. Fitoterapia, 73:217-241.

PIERONI, A., GIUSTI, M.E., \& GRAZZINI, A. 2002. Animal remedies in the folk medicinal practices of the Lucca and Pistoia Provinces, Central Italy. In: FLEURENTIN, J., PELT, J.M. \& MAZARS, G. (Eds.). Des sources du savoir aux médicaments du futur/from the sources of knowledge to the medicines of the future, Proceedings of the fourth European Colloquium of Ethnopharmacology, IRD Éditions. Paris, France, pp. 371-375.

PINA, L.D.E. 1946. Flora e fauna brasílicas nos antigos livros médicos portugueses. Brasilia. 3:149-357.

R DEVELOPMENT CORE TEAM: A language and environment for statistical computing. 2017. - R Foundation for Stat. Comput., Vienna, Austria.

RIBEIRO, G.C. \& SCHIAVETTI, A. 2009. Conocimiento, Creencias y Utilización de la mastofauna por los pobladores del Parque Estatal de la Sierra de Conduru, Bahia, Brasil. In: COSTA-NETO, E. M., SANTOS-FITA, D. \& CLAVIJO, M.V. (Eds.). Manual de Etnozoología: Una guia teóricopráctica para investigar la interconexión del ser humano son los animales. Tundra Ediciones, Valencia, España. 
RODRIGUES, E. 2006. Plants and animals utilized as medicines in the Jaú National Park (JNP), Brazilian Amazon. Phytother Res, 20:378-391.

ROSA, I.L. et al. 2011. Fisheries and trade of seahorses in Brazil: historical perspective, current trends, and future directions. Biodivers Conserv. doi:10.1007/s10531-011-0068-2

SCHNURRENBERGER, P.R. \& HUBBERT, W.T. 1981. An outline of the zoonoses Ames, IA: Iowa State University Press.

SECRETARIA ESTADUALDE MEIO AMBIENTE E RECURSOS HÍDRICOS - Sema. 2005. Plano de Manejo do Parque Estadual da Serra do Conduru. Bahia.

SEIXAS, C.S. \& BEGOSSI, A. 2001. Ethnozoology of fishing communities from Ilha Grande (Atlantic forest coast, Brazil). J Ethnobiol, 21:107-135.

SILVA, H. 1898. A Caça no Brasil Central. Rio de Janeiro, Oficinas da Livraria Moderna.

SILVA, M.L.V., ALVES, A.G.C. \& ALMEIDA, A.V. 2004. A zooterapia no Recife (Pernambuco): uma articulação entre as práticas e a história. Biotemas, 17(1):95-116.

SILVA, N.L.G. et al. 2010. Zooterápicos utilizados em comunidades rurais do município de Sumé, semiárido da Paraíba, Nordeste do Brasil. In: COSTA-NETO, E.M.C. \& ALVES, R.R.N. (Org.). Zooterapia: os animais na medicina popular brasileira. Recife: NUPEEA. p. 243-267.

SILVANO, D.L. \& PIMENTA, B.V.S. 2003. Diversidade e distribuição de anfíbios na Mata Atlântica do sul da Bahia. In: Prado PI. et al. (org.). Corredor da Biodiversidade da Mata Atlântica do Sul da Bahia. Publicação em CD-ROM, Ilhéus, IESB/CI/CABS/UFMG/UNICAMP.

SOCIEDADE BRASILEIRA DE HERPETOLOGIA. 2016. Herpetologia Brasileira. v. 5. n. 3.

SOUTO, F.J.B, SILVA, C.S. \& SOUZA, A.F. 2000. Uma abordagem etnoecológica sobre a medicina popular em Andaraí, Chapada Diamantina, Bahia, Brasil. In: Anais do I Simpósio Estadual de Etnobiologia e Etnoecologia. Feira de Santana.
SOUTO, W.M.S et al. 2011. Parallels between zootherapeutic practices in ethnoveterinary and human complementary medicine in northeastern Brazil. Journal of Ethnopharmacology, 134: 753-767.

TAYLOR, L.H., LATHAM, S.M. \& MARK, E.J. 2001. Risk factors for human disease emergence. Philosophical Transactions of the Royal Society of London. Series B: Biological Sciences 356:983-989.

TEMPONE, A.G. et al. 2008. Antileishmanial and antitrypanosomal activity of bufadienolides isolated from the toad Rhinella jimi parotoid macrogland secretion, Toxicon, vol. 52, no. 1, pp. 13-21, 2008.

Van Vliet N, et al. 2017. Carne de animais selvagens e saúde humana: Avaliar a evidência em florestas tropicais e sub-tropicais. Ethnobiology e Conservação 6: $1-45$

VARNHAGEN, F.A. 1860. A caça no Brazil, ou, Manual do caçador, em toda a América tropical, acompanhado de um glossário dos termos usuaes de caça. Rio de Janeiro, Em casa de E. \& H. Laemmert.

VÁZQUEZ, P.E. et al. 2006. Uso medicinal de la fauna silvestre en los Altos de Chiapas, México. Interciencia, v. 31, p. 491-499.

VUOTO, L.D. 1999. Recolección animal entre los tobas de Formosa. In: ASCHERO, C., KORSTANJE, M.A. \& VUOTO, P. (Eds.). En los tres reinos: Prácticas de recolección en el Cono Sur de América. Instituto de Arqueología y Museo. Facultad de Ciencias Naturales e Instituto Miguel Lillo, Universidad Nacional de Tucumán, pp 253-260.

ZHANG, L., HUA, N. \& SUN, S. 2008. Wildlife trade, consumption and conservation awareness in southwest China. Biodivers Conserv 17:14931516. doi:10.1007/s10531-008-9358-8.

ZWEBER, A. 2002. Cultural competence in pharmacy practice. American Journal of Pharmaceutical Education, 66, 172-176.
Received: 01/07/2019

Revised: 06/09/2019

Accepted: 30/09/2019

Published online: 10/01/2020 